\title{
CHIC2/ETV6 Fusion Protein
}

National Cancer Institute

\section{Source}

National Cancer Institute. CHIC2/ETV6 Fusion Protein. NCI Thesaurus. Code C99669.

A fusion protein encoded by the CHIC2/ETV 6 fusion gene. This protein is comprised of approximately $110 \mathrm{~N}$-terminal amino acids from the cysteine-rich hydrophobic domain 2 protein fused to the C-terminal half of the transcription factor ETV6 protein, including the helix-loop-helix and ETS DNA-binding domains. 